\title{
Occupational asthma due to polyvinyl chloride and methylmethacrylate, "hidden in an adhesive"
}

\author{
Silvia Uriarte Obando*, Mar Fernández-Nieto, Joaquín Sastre \\ From EAACI International Severe Asthma Forum (ISAF 2012) \\ Gothenburg, Sweden. 11-13 October 2012
}

Polyvinyl chloride (PVC) is a thermoplastic polymer widely used in industry, reflected in the number of tons consumed annually in the world. We present a 48 year old male patient with no history of atopy, plumber by profession for 30 years, developed progressive dyspnea and dry cough in the last 3 years, triggered in the work environment and persist outside it, related it to manipulate an adhesive called Tangit, whose components are PVC powder and methylmethacrylate. Never presented skin lesions, or used protection. Were performed blood tests, chest radiography, skin tests, spirometry, bronchodilator test and fraction of exhaled nitric oxide, methacholine challenge test was positive (PC 20, $8 \mathrm{mg} / \mathrm{dl}$ ). After signing informed consent, we performed specific bronchial provocation (SBP) in a $7 \mathrm{~m}^{3}$ dynamic chamber for 30 minutes of cumulative exposure, simulating working conditions with placebo, the Tangit adhesive provoked a late asthmatic response with a maximal fall in FEV1 of $33 \%$ at 7 hours, PVC powder and methylmethacrylate generated dual asthmatic responses, with a maximum drop of $17 \%$ at $30 \mathrm{~min}$ utes and $17.3 \%$ at 7 hours, $22 \%$ at 2 minutes and $20 \%$ at 9 hours, respectively. The patient during the study was on sick leave from to 24 months. We report a case of occupational asthma by PVC and methylmethacrylate, shown by specific bronchial challenge in a plumber exposed to these agents. There are cases of occupational asthma published by the degradation products of PVC or manipulated workers manufacturing bottle caps1 and packaging. It is the first case of occupational asthma by PVC content in an adhesive. So far been known that adhesives containing acrylates, capable of inducing asthma.

Published: 3 May 2013

Fundación Jiménez Díaz, Allergy Department, Spain
doi:10.1186/2045-7022-3-S1-P32

Cite this article as: Obando et al:: Occupational asthma due to polyvinyl chloride and methylmethacrylate, "hidden in an adhesive". Clinical and Translational Allergy 2013 3(Suppl 1):P32.
Submit your next manuscript to BioMed Central and take full advantage of:

- Convenient online submission

- Thorough peer review

- No space constraints or color figure charges

- Immediate publication on acceptance

- Inclusion in PubMed, CAS, Scopus and Google Scholar

- Research which is freely available for redistribution (c) 2013 Obando et al; licensee BioMed Central Ltd. This is an Open Access article distributed under the terms of the Creative Commons Attribution License (http://creativecommons.org/licenses/by/2.0), which permits unrestricted use, distribution, and reproduction in any medium, provided the original work is properly cited. 